\title{
Expression of Vimentin and GFAP Protein of Cerebral Cortex and Its Impact on Corticogenesis Disorder as a Result of 2-Methoxyethanol
}

\author{
Expresión de Vimentina y Proteína GFAP de la Corteza Cerebral y su Impacto \\ en el Trastorno de Corticogenesis como Producto del 2-Metoxietanol
}

\author{
Yulia Irnidayanti* \& Win Darmanto***
}

IRNIDAYANTI, Y. \& DARMANTO, W. Expression of vimentin and GFAP protein of cerebral cortex and its impact on corticogenesis disorder as A result of 2-Methoxyethanol. Int. J. Morphol., 31(3):802-808, 2013.

SUMMARY: One of the plastic base material, widely used in the plastics industry in various countries, is a ester phthalate. These compounds will be oxidized in the body to 2-methoxyethanol (2-ME). Effect of 2-ME on human health and the environment depends on the number, duration and frequency of exposure. 2-ME and its metabolites in the body can damage cells and tissues. The body can be exposed by 2-ME through the air, water and soil. Western blot results showed that the protein Vimentin was detectable in the control group at GD-11 to 17, meanwhile GFAP protein was detachable in the control group at GD- 12 to GD-18. After administration 2-ME, the expression of Vimentin protein were changed, and started at GD- 12 up to GD-18. whereas the expression of GFAP protein began at GD11 up to GD-17. The Changes on timetable protein expression of Vimentin and GFAP affect corticogenesis disorder. The disorder caused by the existence of these proteins as a result of 2-Methoxyethanol. Disorder of corticogenesis process were sub-plate and cortical plate of the cerebral cortex of fetus brains of mice at GD-18. Generally, it can be concluded that changes in protein expression of Vimentin and GFAP caused by 2-ME. The Vimentin more important during the period of fetal brain development. GFAP and Vimentin is a protein involved in response to damage caused by a teratogenic agent, so that cells in the cerebral cortex, has dedifferentiation.

KEY WORDS: 2-methoxyethanol; Vimentin; GFAP; Cerebral cortex; Brain.

\section{INTRODUCTION}

Plastic is commonly used for a variety of human activities. One of the chemicals that are added in the manufacture of plastics to increase flexibility, transparency and resistance are the phthalate esters. This compound is a multifunctional chemical that are used in a variety of consumer products including cosmetic and personal care products. Phthalates are used in large quantities as plasticizer, in plastic products as paint, glue, putty, pharmaceutical products (enteric coating of oral pills, viscosity control agents, surfactants and stabilizers), and medical device (surgical vinyl gloves, bloods bags, tube and dialysis equipments), cosmetics (Agency for Toxic Substances and Disease Registry, 2001, 2002; Schettler, 2006). In Sweden, about 5000-6000 tons of phthalates are used per year. Usually, phthalates are not chemically bound to the base of plastic material and can be released and exposed. People may be exposed in the work environment, via food plastic containers and via inhalation of domestic waste environment (Wormuth et al., 2006). Dermal exposure via clothes and cosmetics may also occur. Small population groups may be exposed via medical equipment. Globally, more 18 billion pounds of ester phthalates are used annually and toxicity of these chemicals occurs through ingestion, inhalation, injection intravenous and dermal exposure on a daily basis (Adibi et al., 2008).

Once a pregnant woman is exposed, phthalates can cross the placenta and enter fetal circulation (Mose et al., 2007). Phthalates have been detected in physiologically relevant compartment in pregnant women and the developing fetus, such as maternal urine (Adibi et al., 2003; Swan et al., 2005), cord blood (Latini et al., 2003), meconium (Kato et al., 2005), placenta (Mose et al.) and amniotic fluid (Silva et al., 2004). 
In the body, phthalates can undergo phase oxidation. Methoxyethanol (ME synonymous with Ethylene glicol monomethyl Ether), is metabolite of ester phthalates, causes significant hematologic and central nervous system disturbances following occupational exposure (Hardin, 1983). 2-ME, it is also known potentially to cause abnormalities, for example excencephaly (Darmanto et al., 1998). The brain is an important organ, because the process of brain formation involves cell proliferation, cell migration and interactions, cell adhesion, differentiation and morphogenesis. The mechanism involves extracellular matrix proteins. The pattern of expression depends on tissue differentiation and temporary disruption of the extracellular proteins expression, may cause impaired cell interaction mechanism, which may ultimately disrupt the developmental process.

Based on the research we have done on embryos, at GD-10th, showed that the brain of mice have been expressed extra-cellular protein, fibronectin, tenascin, Vimentin, neurofilament and neural cell adhesion molecule.Vimentin gen was expressed very high compared to others (Irnidayanti et al. 2011). This data also was supported by the results of previous studies, in treated groups of the brains of embryo mice at GD-12th, from dams were given 2-ME at GD-10th, are showed Vimentin gene expression level mRNA is very high too (Irnidayanti et al., 2010) and there are different levels of Vimentin and GFAP protein until at GD-11 GD-18 (Irnidayanti et al., 2012). Therefore, we suspect that the protein extracellular Vimentin played a role in the process of brain development, especially in the process of corticogenesis. Thus we want to know, are changes of expression GFAP and Vimentin protein in brain due to the plastic base material, methoxyethanol during the period of brain development, caused corticogenesis disorder.

\section{MATERIAL AND METHOD}

Experimental Animals. Mus musculus (Swiss webster) mice were used as experimental, from Animal House and toxicology laboratories University of Indonesia. Rearing the animals was done in a room at $23-270 \mathrm{C}$ and $83 \%$ humidity. Food and water were given ad libitum. When female mice achieved their sexual maturity (10-12 weeks), they were mated with a male (1:1). A vaginal plug detected the following morning was defined as day 0 of gestation day (Rugh, 1968).

Material, dosage and Sample Collection. 2-ME in liquid form (Product Number: 285467) was produced by Wako Pure Chemical Industries, Ltd. Japan. 2-ME diluted with sterilized distilled water was administered by intraperitoneal injection at a dose of $7,5 \mathrm{~m} \mathrm{~mol} / \mathrm{kg}$ body weight on the mice pregnant at GD-10. The Control mice were only given sterile distilled water with the same dose.

All mice dams were killed by anaesthetized and perfused at GD-11th,12th,13th, 14th,15th, 16th, 17th, and 18 th. The pregnant mice were cut opened, next uterus was taken and put in falcon tube containing buffer solution. Uteri were opened, embryo was taken and brains were isolated, under stereomicroscope and were stored at $-20 \mathrm{oC}$ until final analysis.

Protein Precipitation. Brain samples were put in Eppendorf tubes, and kept in box which contained dry ice. Protein precipitation of brain fetuses ware used celLytictm M Cell Lysis (Sigma C2978), then destroyed with a pellet pestle and homogenized at $4 \mathrm{oC}$. Cellular debris was separated by centrifugation at $11.000 \mathrm{rpm}, 40 \mathrm{C}$ for 15 minute. Ultimately, extract proteins were obtained.

Measurement of Protein Concentration. This calculation is done with BCA Smart Kit Cat No. 21071 Japan. Kit consists of solution A, solution B and solution of BSA 2 $\mathrm{mg} / \mathrm{ml}$. BSA standard solution required for calibration of the instrument nanodrops, in order to obtain the graph straight. Preparation of BSA solution made by adding stock solution of BSA and sterile water with increasing concentration. The next step before measuring the protein content is to make the solution of the WS (working solution). Ways of making this solution is by adding solution A and solution B with a ratio of 50:1. Pipette $5 \mu \mathrm{l}$ of each standard or protein sample replicate into a micro plate well, and then added $100 \mu \mathrm{l}$ of the working solution to each well and mix plate thoroughly on the plate. Cover plate and incubated at $37^{\circ} \mathrm{C}$ for 30 minute, final step the micro plate samples were cooled at room temperature, and then absorban level measured with nanodrops 2000 by Termo.

One-dimensional Electrophoresis SDS. Polyacrylamide gel consists of "separating gel" $10 \%$ and "stacking gel" solution. Marker protein SeeBlue plus-2 prestained standard product Invitrogen cat no. LC5925. Control positif ware used A10 cell lysate sc-3806 lot K1810 as Vimentin protein and mouse brain extract sc-2253 lot D2011 as GFAP protein. Proteins were electrophoresis in accordance to instruction manual from invitrogen. Gel results of electro-phoresis removed from the tool carefully and ready to be transferred to a membrane nitrocellulose.

Western Blot. To detect the membrane using a kit iBlot Gel Transfer Stacks Nitrocellulose, Mini Lot No. NM03111-02 
by invitrogen. These kits consist of, iBlot Anode stack bottom mini, iBlot katode stack top mini, iBlot disposable sponge. Non-specific antibody binding to the membrane nitrocellulose was blocked with 1x TBST 5\% non-fat dry milk at room temperature or incubated overnight at $4 \mathrm{oC}$. The blot was then incubated using an antibody against, mouse monoclonal GFAP sc 33673 lot. A2510 and Vimentin sc 32322 lot. E1011 at diluted 1: 200 as the primary antibody. Antigen-antibody reaction was detected by anti $\operatorname{IgG}$ goat anti mouse F(ab')2-HRP 1:1000 as the secondary antibody. Proteins were stained with AEC solution.

Paraffin Methods. The dams of mice were anaesthetized using chloroform, then perfused with saline $1 \%$ and $4 \%$ PFA solution. Fetal brains were fixed in 4\% PFA solution for 4 days. Further dehydration in alcohol gradually with increasing concentration. Purification was done in a solution of alcohol-xilol, xilol-pure and paraffin infiltration was done in an oven at a temperature of 57-600C. Brain specimens were sliced with rotary microtome, a thickness of $5 \mathrm{~mm}$, and staining of slide with HE and immunohistochemical solution.

\section{RESULTS}

Figure 1 shows that the Vimentin protein expression in the brains of control mice embryos, begins at gestation day 11 to 17 . The Vimentin protein bands in the treated group, have began to be expressed at gestation days 12th to 18 days, and the protein band are very thick (Fig. 2).

Expression protein GFAP in embryo mice brain of control began on gestation days 12 to 18 (Fig. 3), meanwhile expression of GFAP protein on brain mice treatment begins at gestation days 11 up to 17 (Fig 4). When compared to Vimentin and GFAP protein expression between control and

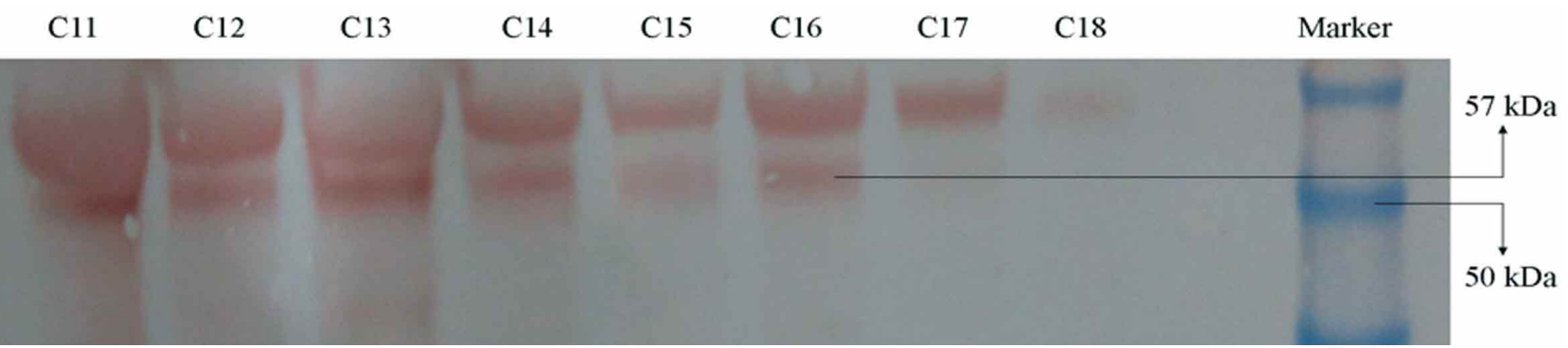

Fig. 1. Western blotting with the Vimentin antbodyi. Arrow indicates Vimentin protein expression (57 kDa) of brain control embryo mice at gestation days 11 to 18 .

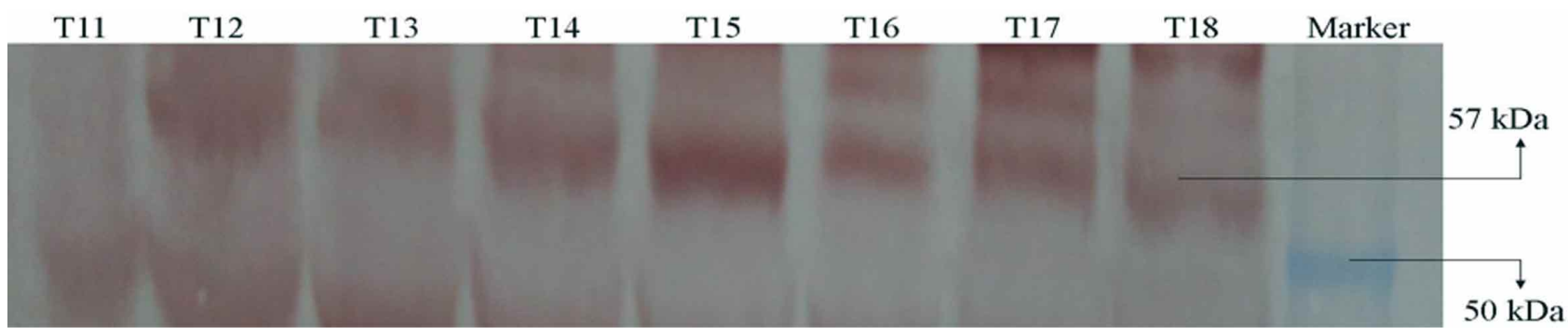

Fig. 2. Western blotting with the Vimentin antibody. Arrow indicates Vimentin protein expression (57 kDa) of brain treatment embryo mice at gestation days 11 to 18 .

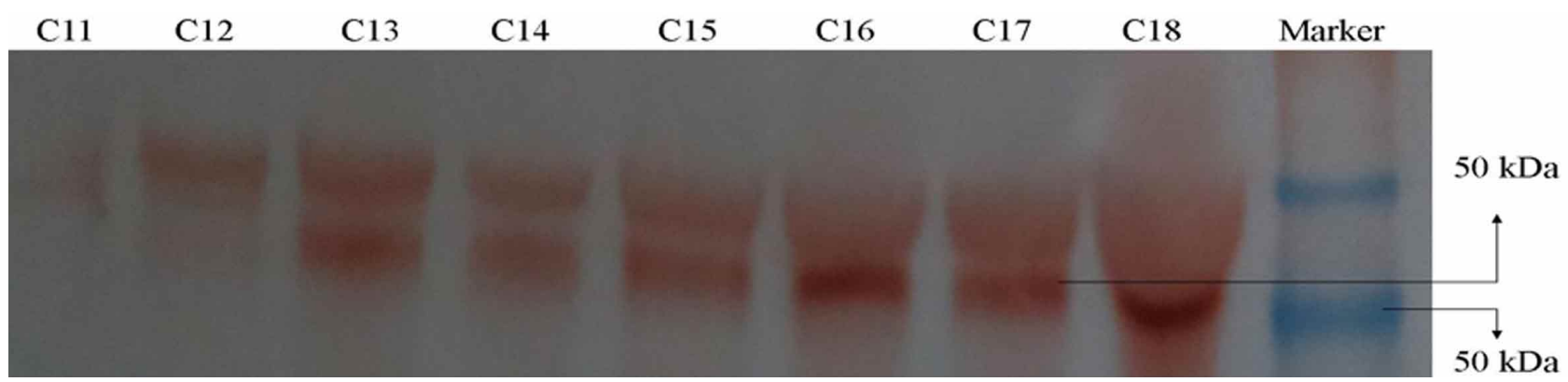

Fig. 3. Western blotting with the GFAP antibody. Arrow indicates GFAP protein expression (50 kDa) of brain control embryo mice at gestation days 11 to 18 . 
treatment, it appears that there is a timetable change protein expression, both in Vimentin and GFAP. Changes in protein expression timetable does, of course disturb the formation of a layer of the cerebral cortex.

Cross sections of the cerebral cortex of mice embryo control at GD-14th day showed that there are no differences in histological structure, with cerebral cortex treatment (Fig. 5). The cerebral cortex of control mice at GD-14th, can be divided into three layers, VZ (ventricular zone), IZ (intermediate zone) and MZ (marginal zone). When compared with mice treated fetal cerebral cortex at GD-14th, showed no difference when compared with control.

Histological structure of the cerebral cortex of fetal mice treated at GD-18th, showed a more advanced structure of the cerebral cortex of mice fetus at GD-14th. The cerebral cortex control in mice at GD-18th consists of 5 layers (Fig. 7). The arrangement of layers from the outside to the inside consists of marginal zone (MZ), cortical plate (CP), sub plate (SP), intermediate zone (IZ) and ventricular zone
(VZ). In the marginal zone (MZ), located under meninges. Ventricular zone located close to the ventricular cavity of the brain, where cells actively proliferate.

In this research the layers of the cerebral cortex of the fetal brain treatment at GD-18th showed a difference with a layer of the cerebral cortex of the fetal brain controls at GD-18th days. Cross section the cerebral cortex of the brain of fetal mice treated at GD-18th, SP and CP boundary layer is relatively less clear and is made up of nerve cells that are not dense or loose, and irregular (Figure 8), compared with control fetal brain cortex at GD-18th (Figure 7). The $\mathrm{CP}$ layer of the cerebral cortex of fetus control mice at GD18th, a number of cells appear that are composed of solid, regular. $\mathrm{CP}$ boundary of fetal cerebral cortex control mice at GD-18th, is clear (Fig 7). In Molecular zone (MZ) of fetal mouse cerebral cortex controls at GD-18th, found many glial cells. This is different from with a layer of MZ fetal cerebral cortex of mice treated at GD-18th, which glial cells is relatively rare.

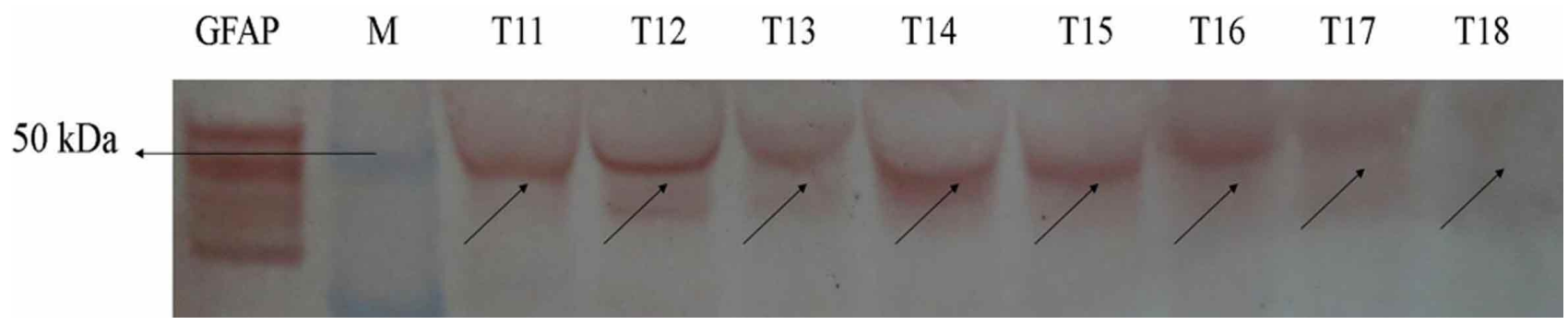

Fig. 4. Western blotting with the GFAP antibody. Arrow indicates Vimentin protein expression (50 kDa) of brain treatment embryo mice at gestation days 11 to 18 .

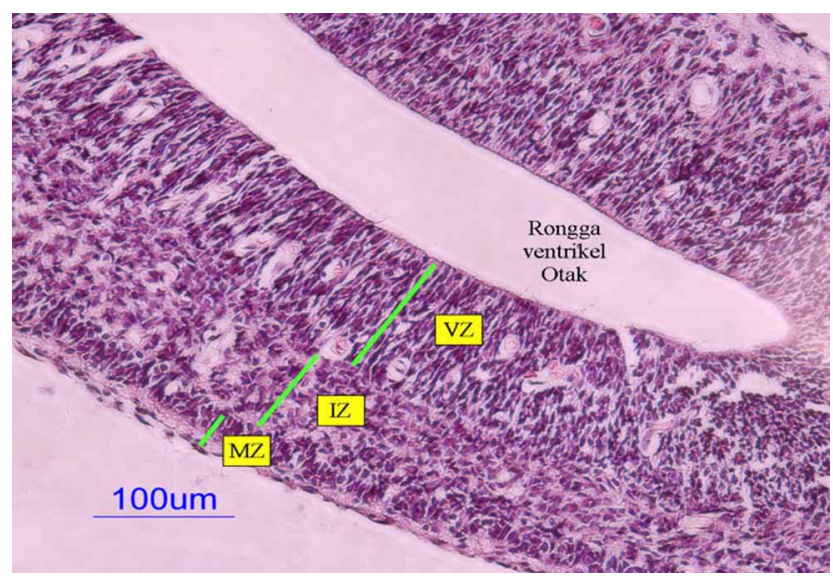

Fig. 5. Cross section of cerebral cortex of control fetus mice at GD-14th (10x20, HE) MZ: Marginal Zone, IZ: Intermediate zone, $\mathrm{VZ}$ : Ventricular Zone.

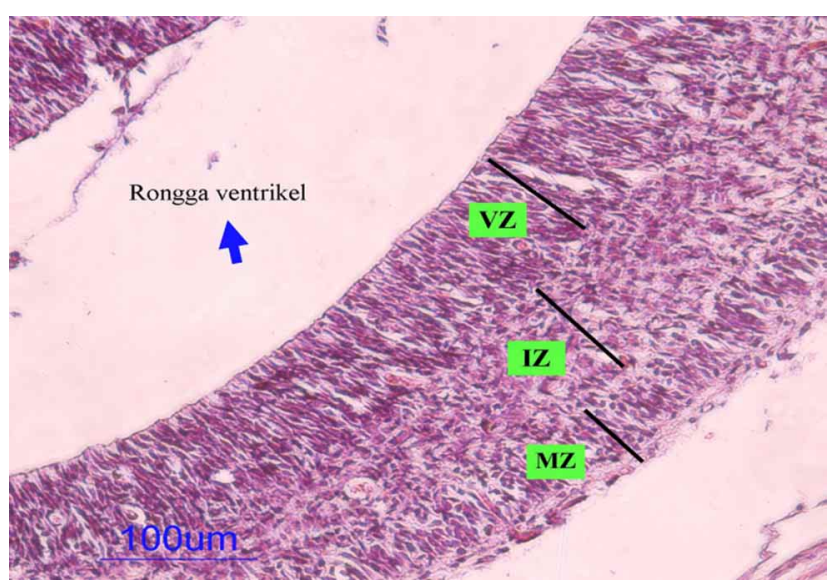

Fig. 6. Cross section of cerebral cortex of treatment fetus mice at GD-14th (10x20, HE) MZ: Marginal Zone, IZ: Intermediate zone, VZ : Ventricular Zone. 


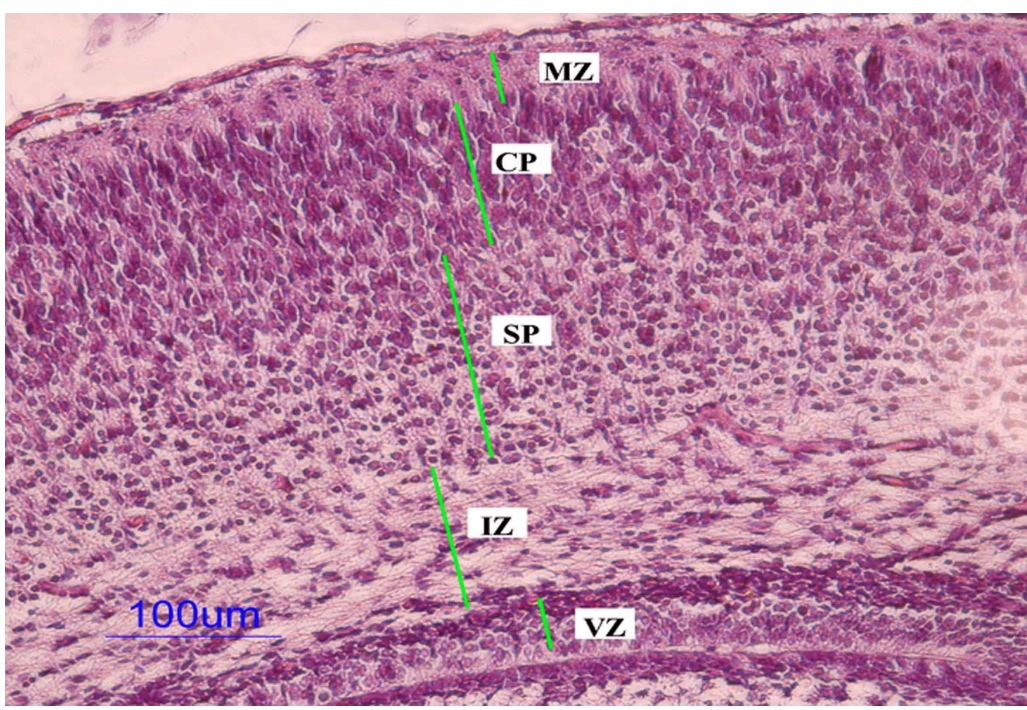

Fig. 7. Cross section of cerebral cortex of control fetus mice at GD-18th (10x20, HE) MZ: Marginal Zone, CP : Cortical Plate, SP: Sub Plate, IZ: Intermediate zone, VZ Ventricular Zone

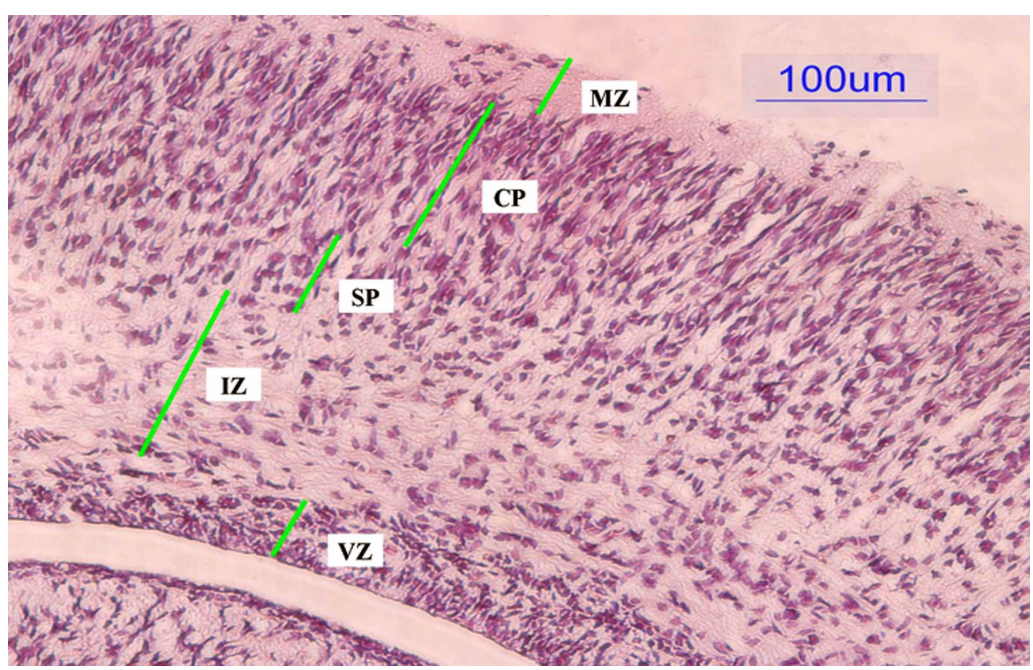

Fig. 8. Cross section of cerebral cortex of control fetus mice at GD-18th (10x20, HE). MZ: Marginal Zone, CP : Cortical Plate, SP: Sub Plate, IZ: Intermediate zone, $\mathrm{VZ}$ : Ventricular Zone.

\section{DISCUSSION}

The research carried out indicates that the protein Vimentin in embryonic brain control group, began to be expressed at gestation days $11^{\text {th }}$ up to $17^{\text {th }}$. This suggests that the protein Vimentin is necessary for the proliferation of neuroepithelial cells. Because in proliferation stage, neural epithelialial cells are expressed in Vimentin protein (Sheppard et al., 1995) and in the brain tissue, Vimentin can be detected in embryo at gestation day 11 , an early stage of mitotic. Vimentin protein found in radial fibers of the neural tube, particularly in ventricular cells of brain that are dividing
(Schnitzer et al., 1981). Cell proliferation is the earliest processes in brain development, which occurs at gestation days 10 up to 12 and at gestation days 13th, entering the phase of organogenesis (Rugh).

This data supported by Stagaard \& Møllgard (2004), who said that the epithelialial cells from human embryos and fetal brain 4 16 weeks of age, showed positive for Vimentin protein. It is suggested that all neuroepithelial cells in vivo differentiate to a stage where they express Vimentin, and that vimentin may have a functional role in cellular movements during the inter kinetic nuclear migration. We conclude that Vimentin protein was first expressed at gestation day 11, and in these stages, cells in ventricular zone still proliferate

Vimentin is a marker for a distinct cell lineage during early Central Nerve System (CNS) development. Vimentin protein expression in the brain of embryos treated with 2-methoxyethanol show a change. Changes in protein expression of vimentin, was on going at gestation day 18. While in the control group, expressed Vimentin protein only up to day 17. It is estimated that the administration of 2methoxy-ethanol at gestation day 10 , effect on the protein expression of Vimentin. Therefore, giving 2-ME disrupt timetable Vimentin protein expression, the expression is delayed. Thus, embryonic brain development which should occur at late gestation day 13 , does not take a place because the proliferation process was still continue until at gestation day 18 . We suspect that at gestation day 11 the point of the healing process occurs. The newly formed nerve cells are directed to replace injured cells in, the place where nerve cells participate in the process of repair and healing. After the healing process, which occurs at the 11th day of gestation, Vimentin protein expression in the treated group is still present, because the cells are still in stages of preparation of proliferation.

In previous studies it is shown that the expression of Vimentin protein is very high (Irnidayanti et al., 2012), but the function of most of these proteins may occur, if its presence together with GFAP protein at the timetable and appropriate number of levels. In mice, rats and humans, increase in 
expression of GFAP in astrocytes occurs gradually through life (Eng et al., 2000). In rat, GFAP was first expressed in the embryonic brain ventricles at the $16^{\text {th }}$ day of gestation in late gestation (Dudprey \& Paulin, 1993). The results of the immunohistochemical studies showed that GFAP protein was first detected in embryonic brain at $14^{\text {th }}$ day of gestation and on the spinal cord at $16^{\text {th }}$ day of gestation.

In treated group, GFAP protein expression on brain embryo began at $12^{\text {th }}$ day of gestation. After the healing process, which occurs at gestation day 11, GFAP protein expression in the treated group began to be expressed at GD 11. This is caused by the cells are still in stages of proliferation preparation. Administration of 2-methoxyethanol is causing astrocytes responsive. If there is damage to brain tissue, the first response of the cell is the astrocyte cell. Progressively, reactive astrocytes will change gene expression and cellular changes. These cells have a physiological role in brain function. Through the release of neurotrophic factors in astrocyte-neuron path, is a way to maintain homeostasis of the central nervous system (Brahmachari et al., 2006).

Recently it has been demonstrated that astrocytes are cells, which in the brain are immunocompetent (Dong \& Benveniste, 2001). After they are activated, astrocytes cells secrete various neurotoxic substances and increases the level of expression of GFAP (Eng \& Ghirnikar, 1994). It is clear that expression of GFAP protein in the treated group, obviously caused by the compound 2-ME. This situation caused astrocytes to become reactive and express neurotrophic factors, and then secrete GFAP. However, expression of GFAP is very dependent on the level of reactive astrocyte damage. In the research that was done it is shown that the GFAP and Vimentin is always expressed together. This estimated, protein Vimentin is very necessary for tissue repair and healing processes of the brain that were damaged as a result of 2-methoxyethanol.

In the research carried out it is noted that the timetable change of Vimentin and GFAP protein expression will impact on histological cortex cerebral structure of the brain. One of the molecular processes in the brain development is corticogenesis. In this process, proliferation of neuroephitellium cells takes place at GD-11th up to GD-17th (Takahashi et al., 1995), before neurogenesis period. Therefore, administration 2-ME at GD-10th, thought interfere process of cell proliferation and lamination of the cerebral cortex. So administration 2-ME affects cells that are proliferating. Although there are recovery processes in the cortex layer, but the process is not able to improve the process corticogenesis that have been occurred.

\section{CONCLUSION}

The Changes of expression Viementin and GFAP protein caused by treatment of compound 2-ME. This has an impact on timetable Vimentin and GFAP protein expression, leading to the disruption of proliferation, and interfere the process of lamination in the cerebral cortex.

\section{ACKNOWLEDGMENTS}

We thank Aulia Ahmad, Ph.D from the University of Indonesia and Prof. Yasuhiro Yamashiro, Ph.D from Yamaguchi University, Japan. This research was done by Research Grant of DIKTI Indonesia-2012 and collaborated by Yamaguchi University, Japan.

IRNIDAYANTI, Y. \& DARMANTO, W. Expresión de vimentina y proteína GFAP de la corteza cerebral y su impacto en el trastorno de corticogenesis como producto del 2-Metoxietanol. Int. J. Morphol., 31(3):802-808, 2013.

RESUMEN: Uno de los materiales a base de plástico, ampliamente utilizado en la industria en varios países, es un éster de ftalato. Estos compuestos se oxidan en el cuerpo a 2-metoxietanol (2-ME). El efecto del 2-ME en la salud humana y el medio ambiente depende de la cantidad, duración y frecuencia de exposición. El 2-ME y sus metabolitos en el cuerpo puede dañar las células y tejidos. El cuerpo puede ser expuesto al 2-ME a través del aire, agua y suelo. Los resultados de Western blot mostraron que la proteína vimentina fue detectable en el grupo de control en GD-11 a 17, por su parte proteína GFAP fue detectable en el grupo de control en GD-12 a GD-18. Después de la administración de 2-ME, la expresión de la proteína vimentina cambió, y comenzó a detectarse en GD-12 hasta GD-18, mientras que la expresión de la proteína GFAP se inició en GD-11 hasta GD-17. Los cambios en el momento de expresión de las proteínas vimentina y GFAP afectan produciendo trastornos de la corticogénesis. El trastorno causado por la existencia de estas proteínas como resultado de 2-metoxietanol a nivel del proceso corticogénesis fue en la subplaca y la placa cortical de la corteza cerebral del cerebro de fetos de ratones en GD-18. En general, se puede concluir que existen cambios en la expresión de las proteínas vimentina y GFAP causados por el 2-ME. La vimentina es muy importante durante el período de desarrollo del cerebro fetal. GFAP y vimentina son proteínas implicadas en la respuesta a los daños causados por un agente teratogénico, de modo que las células en la corteza cerebral presentan desdiferenciación.

PALABRAS CLAVE: 2-metoxietanol; Vimentina; GFAP; Corteza cerebral; Cerebro. 


\section{REFERENCES}

Agency For Toxic Substances and Disease Registry. Toxicological Profile For Di-n-Butyll Phthalate. Atlanta, Agency for Toxic Substances and Disease Registry, 2001.

Agency For Toxic Substances and Disease Registry. Toxicological Profile For Di(2-ethyhexy)Phthalate (DEHP). Atlanta, Agency for Toxic Substances and Disease Registry, 2002.

Adibi, J. J.; Perera, F. P.; Jedrychowski, W.; Camann, D. E.; Barr, D.; Jacek, R.; et al. Prenatal exposures to phthalates among women in New York City and Krakow, Poland. Environ. Health Perspect., 111(14):171922, 2003.

Adibi, J. J.; Whyatt, R. M.; Williams, P. L.; Calafat, A. M.; Camann, D.; Herrick, R.; et al. Characterization of phthalate exposure among pregnant women assessed by repeat air and urine samples. Environ. Health Perspect., 116(4):467-73, 2008.

Brahmachari, S.; Fung, Y. K. \& Pahan, K. Induction of glial fibrillary acidic protein expression in astrocytes by nitric oxide. J. Neurosci., 26(18):4930-9, 2006.

Darmanto, W. Efek 2-methoxyethanol terhadap pembentukan somite dan kelainan rangka aksial pada mencit. Proceeding Temu Ilmiah VII, Hiroshima, Japan, 1998. pp.19-22.

Dong, Y. \& Benveniste, E. N. Immune function of astrocytes. Glia, 36(2):180-90, 2001

Duprey, P. \& Paulin, D. What can be learned from intermediate filament gene regulation in the mouse embryo. Int. J. Dev. Biol., 39(3):443-57, 1995.

Eng, L. F. \& Ghirnikar, R. S. GFAP and astrogliosis. Brain Pathol., 4(3):229-37, 1994

Eng, L. F.; Ghirnikar, R. S. \& Lee, Y. L. Glial fibrillary acidic protein: GFAP-thirty-one years (1969-2000). Neurochem. Res., 25(9-10):1439$51,2000$.

Hardin, B. D. Reproductive toxicity of the glycol ethers. Toxicology, 27(2):91-102, 1983.

Irnidayanti, Y.; Darmanto, W. \& Abadi, A. Expression of Level Gen mRNA of Ekstraseluler Protein embrio brain mice black-6 at GD-12 caused by induced 2-Methoxy-ethanol:analysis by Real Time RT-PCR. Berk. Penel. Hayati, 15:171-9, 2010.

Irnidayanti, Y.; Darmanto, W. \& Abadi, A. The Expression of Gen Extracellular Matrix and Cell Adhesion Molecule of Brain Embryo Mice at GD-10 By real time RT-PCR. World Acad. Sci. Eng. Tech., 58:705-8, 2011.

Irnidayanti, Y.; Darmanto, W.; Abadi, A.; Hattori, Y. \& Yamashiro, Y. Differential Expression of Vimentin and GFAP Protein during Brain Development of Mouse Fetuses after Treated with 2-Methoxyethanol. ITB J. Sci., 44 A(4):346-57, 2012.

Kato, K.; Silva, M. J.; Needham, L. L. \& Calafat, A. M. Determination of 16 phthalate metabolites in urine using automated sample preparation and on-line preconcentration/high-performance liquid chromatography/tandem mass spectrometry. Anal. Chem., 77(9):298591, 2005 .

Latini, G.; De Felice, C.; Presta, G.; Del Vecchio, A.; Paris, I.; Ruggieri, F.; et al. In utero exposure to di-(2-ethylhexyl)phthalate and duration of human pregnancy. Environ. Health Perspect., 111(14):1783-5, 2003.

Mose, T.; Mortensen, G. K.; Hedegaard, M. \& Knudsen, L. E. Phthalate monoesters in perfusate from a dual placenta perfusion system, the placenta tissue and umbilical cord blood. Reprod. Toxicol., 23(1):8391, 2007.

Rugh, R. The Mouse: Its Reproduction and Development. Minneapolis, Burgess Publishing Company, 1968.

Schettler, T. Human exposure to phthalates via consumer products. Int. J. Androl., 29(1):134-9; discussion 181-5, 2006.

Schnitzer, J.; Franke, W. W. \& Schachner, M. Immunocytochemical demonstration of vimentin in astrocytes and ependymal cells of developing and adult mouse nervous system. J. Cell Biol., 90(2):43547, 1981.

Sheppard, A. M.; Brunstrom, J. E.; Thornton, T. N.; Gerfen, R. W.; Broekelmann, T. J.; McDonald, J. A.; et al. Neuronal production of fibronectin in the cerebral cortex during migration and layer formation is unique to specific cortical domains. Dev. Biol., 172(2):504-18, 1995.

Silva, M. J.; Reidy, J. A.; Herbert, A. R.; Preau, J. L. Jr.; Needham, L. L. \& Calafat, A. M. Detection of phthalate metabolites in human amniotic fluid. Bull. Environ. Contam. Toxicol., 72(6):1226-31, 2004.

Stagaard, M. \& Møllgard, K. The developing neuroepithelium in human embryonic and fetal brain studied with vimentinimmunocytochemistry. Anat. Embryol. (Berl.), 180(1):17-28, 1989.

Swan, S. H.; Main, K. M.; Liu, F.; Stewart, S. L.; Kruse, R. L.; Calafat, A. M.; et al. Decrease in anogenital distance among male infants with prenatal phthalate exposure. Environ. Health Perspect., 113(8):105661, 2005.

Takahashi, T.; Nowakowski, R. S. \& Caviness, V. S. Jr. The cell cycle of the pseudostratified ventricular epithelium of the embryonic murine cerebral wall. J. Neurosci., 15(9):6046-57, 1995.

Wormuth, M.; Scheringer, M.; Vollenweider, M. \& Hungerbühler, K. What are the sources of exposure to eight frequently used phthalic acid esters in Europeans? Risk Anal., 26(3):803-24, 2006.

\section{Correspondence to:}

Yulia Irnidayanti

Biology Department

Faculty of Mathematic and Science

Jakarta State of University

Jalan Pemuda No 10, 13150 - Jakarta

INDONESIA

Email: irnidayanti@unj.ac.id

Received: 25-01-2013

Accepted: 15-04-2013 